University of Nebraska - Lincoln

DigitalCommons@University of Nebraska - Lincoln

Virology Papers

Virology, Nebraska Center for

1997

\title{
Detection of Bovine Immunodeficiency Virus Antibodies in Cattle by Western Blot Assay with Recombinant gag Protein
}

\author{
Shucheng Zhang \\ Kansas State University, Manhattan \\ Wenzhi Xue \\ Bayer Animal Health, Merriam, KS \\ Charles Wood \\ University of Nebraska-Lincoln, cwood1@unl.edu \\ Qi-Min Chen \\ University of Miami, Miami, FL \\ Sanjay Capil \\ Kansas State University, Manhattan \\ See next page for additional authors
}

Follow this and additional works at: https://digitalcommons.unl.edu/virologypub

Part of the Virology Commons

Zhang, Shucheng; Xue, Wenzhi; Wood, Charles; Chen, Qi-Min; Capil, Sanjay; and Minocha, Harish, "Detection of Bovine Immunodeficiency Virus Antibodies in Cattle by Western Blot Assay with Recombinant gag Protein" (1997). Virology Papers. 180.

https://digitalcommons.unl.edu/virologypub/180

This Article is brought to you for free and open access by the Virology, Nebraska Center for at DigitalCommons@University of Nebraska - Lincoln. It has been accepted for inclusion in Virology Papers by an authorized administrator of DigitalCommons@University of Nebraska - Lincoln. 


\section{Authors}

Shucheng Zhang, Wenzhi Xue, Charles Wood, Qi-Min Chen, Sanjay Capil, and Harish Minocha 


\title{
Detection of bovine immunodeficiency virus antibodies in cattle by Western blot assay with recombinant gag protein
}

\author{
Shucheng Zhang, Wenzhi Xue, Charles Wood, Qi-min Chen, Sanjay Kapil, Harish C. Minocha
}

\begin{abstract}
A western blot assay using purified recombinant bovine immunodeficiency virus gag protein has been developed for detection of bovine immunodeficiency virus antibodies in bovine serum samples. The test was standardized with known bovine immunodeficiency virus positive and negative bovine serum samples and the monoclonal antibody to gag protein. Both naturally and experimentally infected cattle sera demonstrated positive test results. The result of western blot assay was compared with polymerase chain reaction test results in 134 blood samples collected from Kansas. Twenty-six samples tested positive for bovine immunodeficiency virus DNA with polymerase chain reaction $(18.7 \%)$ and 25 were positive for the antibody to gag protein by western blot analysis (17.9\%). Of 26 cattle testing positive using the polymerase chain reaction assay, 24 were antibody-positive by western blot assay, thus establishing a strong correlation between the two tests. The sensitivity and specificity of western blot relative to polymerase chain reaction are 0.92 and 0.99 , respectively. The western blot assay proved to be a specific and sensitive test.
\end{abstract}

Bovine immunodeficiency virus (BIV), a lentivirus of Retroviridae, was isolated originally from cattle with lymphocytosis, lymphadenopathy, neuropathy, and progressive emaciation. ${ }^{25}$ However, clinical disease due to natural and experimental BIV infection has not been documented. ${ }^{4,6,24,26}$ A serological survey, of literature showed that BIV infection is worldwide. ${ }^{1,5,11,12,16,23}$ Although a comprehensive serological survey on BIV infection in the United States is lacking, regional data showed that BIV infection is relatively high. For example, on average, $40 \%$ of beef and $60 \%$ of dairy herds in Louisiana were positive. ${ }^{10} \mathrm{Re}-$ cently, seroprevalence of BIV among cattle herds in Mississippi was reported to be greater than $50 \% .^{23}$

To screen for the naturally infected cattle, different serological approaches have been employed, such as e.g, immunofluorescence assays (IFAs), western blot assay, and enzyme-linked immunosorbant assay (ELISA). ${ }^{23,26,27}$ Although these tests can detect BIV exposure, they may lack specificity or require a large amount of native viral antigen. Because BIV can be propagated well only in primary bovine cell cultures, the use of native viral proteins for serological testing is quite difficult. Recombinant BIV proteins have been expressed in bacteria, insect cells, and eukaryotic cells, and the bacterial recombinant gag and env proteins

From the Department of Diagnostic Medicine/Pathobiology, College of Veterinary Medicine, Kansas State University, Manhattan, KS 66506 (Zhang, Xue, Kapil, Minocha), and the Department of Neurology, School of Medicine, University of Miami, Miami, FL 33136 (Wood, Chen). Current address (Xue): Bayer Animal Health, Merriam, KS 66202. Current address (Wood): Beadle Center of Biotechnology, University of Nebraska, Lincoln, NB 69583.

Received for publication February 2, 1996. have been used to detect BIV antibodies in the experimentally infected animals by western blot analyses. ${ }^{2,21,26,27}$ In this study, purified recombinant BIV gag protein will be used in a western blot assay to detect BIV antibodies in field bovine serum samples.

Polymerase chain reaction (PCR) is a highly sensitive and specific assay that can detect as few as 2 molecules of provirus integrated in the cells. ${ }^{17}$ The sensitivity of the test makes it suitable for detecting BIV infection in cells or tissues, as the level of integrated provirus appears to be very low in lentivirus infection. ${ }^{4}$ PCR has been used to detect BIV DNA in both tissue culture and peripheral blood mononuclear cells (PBMCs) in BIV-infected calves. ${ }^{17-19}$ The DNA of BIV was also successfully amplified by PCR from bovine mammary leukocytes and seminal leukocyte samples. ${ }^{18,19}$ Availability of a sensitive test based on the detection of BIV nucleic acid would confirm the results based on the detection of antibody, especially when virus isolation proved to be difficult.

The present study is designed to use recombinant BIV gag protein as antigen in a western blot assay to detect BIV-specific antibody in field serum samples. The test was validated with known BIV positive and negative sera, and its specificity compared with the PCR test.

\section{Materials and methods}

Expression and purification of recombinant protein. Expression of P26 encoding the BIV gag gene (clone gag-3) in Escherichia coli as a recombinant trpE fusion protein has been reported. ${ }^{2}$ Briefly, E. coli strain RRI transfected with a PATH (plasmid $a$ menable for making trp hybrids) expression vector containing BIV gag gene was grown in PATH medium with tryptophan for $18 \mathrm{hr}$. The culture was then inoc- 
ulated into fresh PATH medium without tryptophan. After 1 hr growth with shaking, $\beta$-indoleacrylic acid ${ }^{\mathrm{a}}$ was added to the medium and the culture was grown for another $3 \mathrm{hr}$ with vigorous shaking to induce recombinant protein expression. The bacterial cells were pelleted at $10,000 \times g$ for $15 \mathrm{~min}$, washed with $10 \mathrm{mM}$ Tris- $\mathrm{HCl}(\mathrm{pH} 7.5)$, resuspended in 2 $\mathrm{mg} / \mathrm{ml}$ lysozyme, ${ }^{\mathrm{a}}$ and placed on ice for $1.5 \mathrm{hr}$ with $10 \%$ octylphenoxy polyethoxy ethanol (NP-40) and $5 \mathrm{M} \mathrm{NaCl}$. The suspension was sonicated on ice to shear bacterial chromosomal DNA. Proteins were pelleted and washed twice with $10 \mathrm{mM}$ Tris- $\mathrm{HCl}$ and $1 \mathrm{M} \mathrm{NaCl}$ and resuspended in 10 $\mathrm{mM}$ Tris- $\mathrm{HCl}$ for storage at $4 \mathrm{C}$. Protein concentration was determined by a protein assay kit. ${ }^{\text {b }}$

Recombinant gag proteins were purified by electrophoresis and electroelution as previously described. ${ }^{2}$ Briefly, the expressed proteins were separated using preparative sodium dodecyl sulfate polyacrylanide gel electrophoresis (SDSPAGE). A clear, thick, white protein band with a molecular weight of $67 \mathrm{kD}$, visualized by soaking in $1 \mathrm{M}$ potassium acetate, was cut off from the gel, diced, and electroeluted using an electroeluter. ${ }^{\mathrm{b}}$ The protein concentration of eluted protein was determined by the protein assay kit, ${ }^{\text {b }}$ and purity was confirmed by SDS-PAGE. Recombinant BIV gag protein was stored at $-20 \mathrm{C}$.

Western blot assay. Purified recombinant gag protein was used as antigen in the western blot assay. The protein was loaded onto a preparative $12.5 \%$ SDS-PAGE mini-gel ${ }^{\mathrm{b}}$ and electrophoresed in Tris-glycine buffer (0.025 M Tris-base, $0.192 \mathrm{M}$ glycine, $0.1 \% \mathrm{SDS}$ ) at $30 \mathrm{~mA} / \mathrm{gel}$ for $1 \mathrm{hr}$. Then, the protein was transferred onto a nitrocellulose membrane $\left(0.45-\mu \mathrm{m}\right.$ pore size) with a transblot apparatus $\mathrm{s}^{\mathrm{b}}$ at $250 \mathrm{~mA}$ for $1 \mathrm{hr}$. The membrane was blocked with $2 \%$ bovine albumin, 0.02 M Tris-base, $0.385 \mathrm{M} \mathrm{NaCl}$, and $0.1 \%$ Tween 20, $\mathrm{pH} 7.5$ (TTBS) at room temperature for $2 \mathrm{hr}$, rinsed 3 times with TTBS, and then cut into 5-mm strips. Tested and control sera were diluted 1:10, 1:20, 1:50, and 1:100 with TTBS in multichannel incubation trays, ${ }^{\mathrm{b}}$ and the strips were put into each channel and incubated overnight at $4 \mathrm{C}$. After washing 3 times with TTBS, the strips were incubated with horseradish peroxidase-labeled goat anti-bovine $\operatorname{IgG}(\mathrm{H}+\mathrm{L})$ $(1: 3,000)^{\mathrm{c}}$ for another $2 \mathrm{hr}$ at room temperature and rinsed twice with TTBS and once with TBS (0.02 M Tris-base, $0.385 \mathrm{M} \mathrm{NaCl}, \mathrm{pH} 7.5)$. Finally, the color was developed with a 4-CN substrate solution (100 ml TBS, $60 \mu \mathrm{l} \mathrm{H}_{2} \mathrm{O}_{2}$, $20 \mathrm{ml}$ ice-cold methanol, and $60 \mu \mathrm{g}$ 4-chloro-naphthol ${ }^{\mathrm{d}}$ ) for $15 \mathrm{~min}$.

Sera from a calf naturally infected with BIV (no. 59) and an experimentally infected calf (no. 49) and a monoclonal antibody to BIV gag protein were included as positive controls in the experiment. Calf sera were diluted up to 1:2,000, and monoclonal antibody was diluted up to $1: 10^{6}$. All dilutions of known positive sera were tested with a different amount of recombinant BIV gag protein ranging from 0.1 to $2 \mu \mathrm{g}$ in each lane. Calf sera positive to either bovine viral diarrhea virus (BVDV), bovine herpes virus-1 (BHV-1), bovine leukemia virus (BLV), or parainfluenza virus type 3 (PI-3) were also included as negative controls in the experiment.

Polymerase chain reaction. Sample DNA was extracted from the clotted bovine blood sample as described for cul- tured cells. ${ }^{14,22}$ Briefly, after removing the serum, the clotted blood was vigorously washed with PBS, and blood cells released from the clot were collected. After centrifugation, the pelleted blood cells were suspended with DNA extraction buffer A $(100 \mathrm{mM} \mathrm{KCl} ; 10 \mathrm{mM}$ Tris, pH 8.3; $2.5 \mathrm{mM}$ $\mathrm{MgCl}_{2}$ ) then incubated with an equal volume of extraction buffer B (10 mM Tris, pH 8.3; $2.5 \mathrm{mM} \mathrm{MgCl}_{2} ; 1 \% \mathrm{NP}-40$; $120 \mu \mathrm{g} / \mathrm{ml}$ proteinase $\mathrm{K}^{\mathrm{a}}$ ) at $60 \mathrm{C}$ for $1 \mathrm{hr}$. DNA was then extracted by phenol/chloroform solution followed by precipitation with isopropanol. After washing with $70 \%$ alcohol and air drying, DNA was suspended in distilled water and DNA concentration was determined.

DNA from bovine blood samples and BIV-positive and BIV-negative control DNA were amplified by PCR using a pair of primers designed to target a 242-base-pair, highly conserved BIV pol gene. A total of $50 \mu \mathrm{l}$ of reaction mixture from the PCR kit, ${ }^{\mathrm{f}} 25 \mathrm{pmol}$ of each primer, and $100 \mathrm{ng}$ of template DNA were combined. Thermal cycling was performed as described by manufacturer's recommendations using a 35-cycle profile: $95 \mathrm{C}$ for $1 \mathrm{~min}, 50 \mathrm{C}$ for $1 \mathrm{~min}$, and $72 \mathrm{C}$ for 2 min. ${ }^{14}$ The PCR products were analyzed by $1 \%$ agarose gel electrophoresis.

Southern blotting: After separation of PCR products on the agarose gel, DNA was transferred onto nitrocellulose membranes by standard blotting techniques. ${ }^{22} \mathrm{~A}$ BIV probe was prepared by incorporation of $\left[\alpha{ }^{32} \mathrm{P}\right] \mathrm{dATP}$ into purified DNA fragments of BIV pol gene using a random primers labeling system. ${ }^{22}$ The probe was hybridized to the DNA on the membranes at $60 \mathrm{C}$ overnight. The blot was washed with increasingly stringent solutions and exposed to X-ray film. ${ }^{\mathrm{h}}$

Field samples. Bovine serum samples with clotted blood were submitted to the Veterinary Diagnostic Laboratory, College of Veterinary Medicine, Kansas State University, from 25 different locations in Kansas during the period from 1994 to 1996 . Most of the cattle were clinically normal, and the samples were submitted for routine serologic tests. More than $90 \%$ of the samples came from beef herds with animals ranging in age from 1 to $2 \mathrm{yr}$. Fifteen samples from beef cattle 3-12 mo old and 10 from breeding herds with ages up to $8 \mathrm{yr}$ were tested.

\section{Results}

Results of the western blot assay using recombinant BIV gag protein as an antigen with different serum samples are shown in Fig. 1. During antigen titration, $0.5 \mu \mathrm{g}$ of purified recombinant BIV gag protein on 5-mm strips produced a sharp band with all of the antibody dilutions of BIV-positive sera. The BIV gag protein showed a strong and specific reaction with the sera collected from calves naturally and experimentally infected with BIV (Fig. 1, lanes 2 and 3) and with the monoclonal antibody against BIV gag protein (Fig. 1, lane 4). Antibody titers in the calf serum samples by this procedure were as high as 1:1,000-1:2,000, and the monoclonal antibody titers in ascitic fluid were up to $1: 10^{5}-1: 10^{6}$ (data not shown). The non-BIV-infected calf serum sample (Fig. 1, lane 5) clearly demonstrated no reaction. Control sera with antibody titers 
$\begin{array}{llllllllllllll}1 & 2 & 3 & 4 & 5 & 6 & 7 & 8 & 9 & 10 & 11 & 12 & 13 & 14\end{array}$

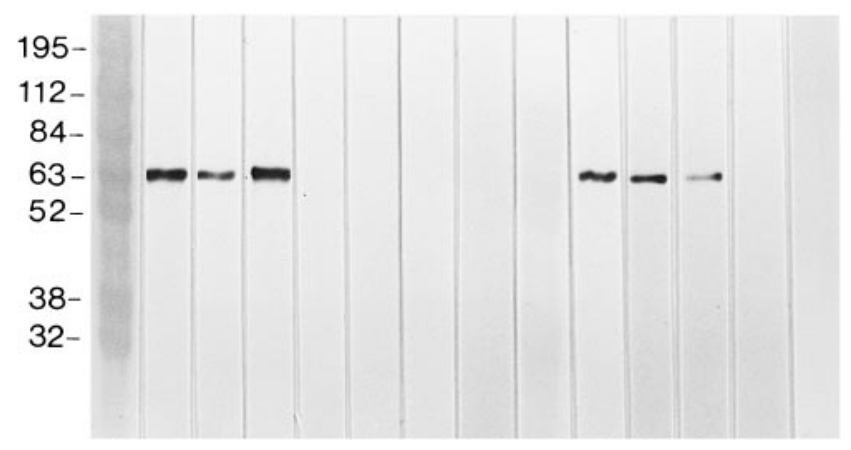

Figure 1. Western blot assay using BIV gag protein as antigen probed with serum from cattle naturally infected with BIV (1:100) (lane 2); serum from cattle experimentally infected with BIV (1: 100) (lane 3); monoclonal antibody to BIV gag protein $(1: 10,000)$ (lane 4); serum from a non-BIV-infected calf (1:20) (lane 5): BLV-, BVDV-, BHV-1-, and PI-3-positive sera (1:20) (lanes 6, 7, 8, and 9); tested BIV-positive serum samples (1:100) (lanes 10, 11, and 12); tested BIV-negative serum samples (lanes 13 and 14). Lane 1 indicates the molecular weight standards.

to other bovine viruses, e.g., BLV, BVDV, BHV-1, and PI-3 (Fig. 1, lanes 6, 7, 8, and 9), did not react with BIV gag protein. Three unknown serum samples showed a strong positive reaction to BIV (Fig. 1, lanes 10,11 , and 12). They were positive even up to 1:400 dilution (data not shown). Two unknown serum samples were negative even at lower dilution (1:20) (Fig. 1, lanes 13 and 14).

The results of the western blot assay and PCR test were compared on 134 bovine blood samples. Visualization of the DNA band on the agarose gel showed that the PCR product amplified from sample bovine blood DNA was as strong as that in control DNA from BIV-infected cells. The identity of the BIV pol gene was confirmed by Southern blot assay with specific DNA probe. Figure 2 shows that PCR products amplified from BIV-infected fetal bovine lung (FBL) cells (lane 1), BIV-infected calf PBMCs (lanes 3 and 4), and some tested bovine blood samples (lanes 6-11) were hybridized with specific BIV pol gene probe. There was no specific PCR product amplified with the DNA from FBL cells (lane 2), from non-BIV-infected calf PBMCs (lane 5), nor from some bovine blood samples (lanes 12 and 13).

Of 134 samples, 26 were DNA-positive to BIV by PCR $(18.7 \%)$ and 25 were antibody-positive to BIV in western blot assay (17.9\%). Among 26 PCR-positive calves, 24 were positive in western blot assay. The sensitivity of the western blot assay relative to PCR is 0.92. Among 108 PCR-negative calves, 107 were negative in western blot assay. The specificity of the western blot assay relative to PCR is 0.99 .
$122344567 \begin{array}{llll}9 & 9 & 1011 & 1213\end{array}$

\section{4-}

$615-$

$369-$

246-

$123-$

Figure 2. PCR amplification products of a 242-bp segment of BIV pol gene confirmed by Southern blot hybridization with ${ }^{32} \mathrm{P}-$ labeled pol gene probe. Positive controls: BIV-infected FBL cells (lane 1) and BIV-infected calf PBMCs (lanes 3 and 4). Negative controls: FBL cells (lane 2), non-BIV-infected calf PBMCs (lane 5), and tested positive (lanes 6-11) and negative (lanes 12-13) bovine blood samples.

\section{Discussion}

The results indicate that the western blot assay with recombinant BIV gag protein is a sensitive, specific, and useful test for diagnosis of BIV infection. BIV gag protein is the core protein in viral particles and is strongly antigenic in eliciting an early, strong, and long-lasting immune response in cattle. ${ }^{27}$ Antibodies to BIV gag protein can be detected as early as 2 weeks after BIV infection and last for at least 2 years. ${ }^{27} \mathrm{~A}$ recombinant BIV gag construct expressed in E. coli yielded a high level of recombinant gag protein, which presents epitopes similar to those of the native viral protein and could be recognized specifically by sera from BIV-infected and -immunized animals. ${ }^{2}$ Using recombinant gag protein as an antigen in the western blot assay for diagnosis of BIV will eliminate the use of native viral protein, which is difficult to produce. No false positive reactions occurred in this test, as have been reported previously for immunofluorescent assay and ELISA. ${ }^{27}$

Western blot assay with recombinant BIV gag protein showed a specific reaction to BIV antibody. In the standardized test, bovine sera with high antibody titer to other bovine retroviruses, such as BLV, gave a negative result. There was no cross reaction with antibodies to other common bovine pathogens, e.g., BVDV, BHV-1, and PI-3. The high specificity of the assay is important since multiple infections of exogous retrovirus and other viral pathogens in animals are common. ${ }^{1,13}$ Although cross reactivity between BIV gag protein and the corresponding antigen of human im- 
munodeficiency virus (HIV) and equine infectious anemia virus (EIAV) is limited, ${ }^{2,9,13}$ it may not affect the specificity of the test since there was no indication that HIV and EIAV can infect cattle and other ruminants.

The retroviruses are protein-encapsulated RNA viruses that replicate via a DNA intermediary during a phase of their life cycles. When BIV infects cells, the provirus DNA can integrate into the host cell genome and become a permanent part of the cell. ${ }^{8}$ However, the BIV integration level in the infected tissue is very low since BIV DNA is not easily detected by in situ hybridization in either tissues or PBMCs of calves experimentally infected with the virus..$^{4,20}$ For demonstration of BIV infection in calves, PCR is probably the best candidate due to its high sensitivity and specificity, especially when virus isolation is not possible. In this experiment, the results of the western blot assay and PCR showed a strong correlation, which further demonstrates specificity and sensitivity of the western blot assay. The PCR test and western blot assay could be alternative means for diagnosis of BIV infection under different circumstances.

BIV infection is worldwide and seropositive cattle have been identified in many countries, including the United States, The Netherlands, Switzerland, Canada, Costa Rica, Venezuela, New Zealand, Australia, and Indonesia. ${ }^{17,10-13,15}$ BIV seroprevalence of $40 \%$ in beef herds, $60 \%$ in Louisiana dairy herds, and 50\% in Mississippi dairy cattle has been reported; whereas sera from eastern or northern parts of the USA are rarely positive for BIV. ${ }^{8,10,23,24}$ In the central regions of the USA, a $21 \%$ seroprevalence of BIV was reported in a Colorado dairy herd based on an ELISA test. ${ }^{5} \mathrm{Al}-$ though accumulated serological screening data on BIV prevalence in randomly selected cattle sera have shown a nonuniform geographic distribution in the USA, ${ }^{3,8}$ there is no clear definitive description of BIV seroprevalence among the cattle population yet. The average of $17.8 \%$ BIV infection in Kansas cattle by western blot assay is further evidence that BIV infection may be widely spread in the country.

\section{Acknowledgement}

This work was supported in part by Public Health Service grant R01 CA62810 from the National Institutes of Health. Published as manuscript 96-98-J from The Kansas Agriculture Experiment Station.

\section{Sources and manufacturers}

a. Sigma, St. Louis, MO.

b. Bio-Rad, Hercules, CA.

c. Kirkegaard \& Perry Laboratory, Gaithersburg, MD.

d. Pierce, Rockford, IL.

e. Dr. H. C. Minocha's laboratory, College of Veterinary Medicine, Kansas State University, Manhattan, KS.

f. Perkin-Elmer, Branchburg, NJ. g. DuPont NEN Research Products, Boston, MA.

h. Eastman Kodak Company, Rochester, NY.

\section{References}

1. Ambroski GF, Lo JL, Seger CL: 1989, Serological detection of multiple retroviral infection in cattle: bovine leukemia virus, bovine syncytial virus and bovine visna virus. Vet Microbiol 20: 247-253.

2. Atkinson B, Liu SQ, Wood C: 1992, Use of bacterial trpE fusion vectors to express and characterize the bovine immunodeficiency like virus core protein. J Virol Methods 36:35-39.

3. Black JW: 1990, Bluetongue and bovine retrovirus committee report. In: Proceeding of the 93rd Annual Meeting of the U.S. Animal Health Association, pp. 150-152. Carter Printing Co., Richmond, VA.

4. Carpenter S, Miller LD, Alexandersen S, et al.: 1992, Characterization of early pathogenic effects after experimental infection of calves with bovine immunodeficiency-like virus. J Virol 66:1074-1083.

5. Cockerell GL, Jensen WA, Rovinak J, et al.: 1992, Seroprevalence of bovine immunodeficiency-like virus and bovine leukemia virus in a dairy cattle herd. Vet Microbiol 31:109-116.

6. Flaming K, VanderMaaten M, Whetstone C, et al.: 1993, Effect of bovine immunodeficiency-like virus infection on immune function in experimentally infected cattle. Vet Immunol Immunopathol 36:91-105.

7. Forman AJ, Gibson CA, Rodwell BJ: 1992, Serological evidence for the presence of bovine lentivirus infection in Australia. Austr Vet J 69:337

8. Gonda MA: 1992, Bovine immunodeficiency virus. AIDS 6: 759-776.

9. Gonda MA, Gravey MS, Pallamsch KJ, et al.: 1990, Development of the bovine immunodeficiency-like virus as a model of lentivirus disease. Dev Biol Stand 72:97-100.

10. Gonda MA, Luther DG, Fong SE, Tobin GJ: 1994, Bovine immunodeficiency virus: molecular biology and virus-host interactions. Virus Res 32:155-181.

11. Horner GW: 1991, Serological evidence of bovine immunodeficiency-like virus and bovine syncytial virus in New Zealand. Surveillance 18:9-14.

12. Horzinek M, Keldermans L, Stuurman T, et al.: 1991, Bovine immunodeficiency virus: immunochemical characterization and serological survey. J Gen Virol 72:2923-2928.

13. Jacobs RM, Smith HE, Gregory B, et al.: 1992, Detection of multiple retroviral infections in cattle and cross-reactivity of bovine immunodeficiency-like virus and human immunodeficiency virus type 1 proteins using bovine and human sera in a western blot assay. Can J Vet Res 56:353-359.

14. Kashanchi F, Liu ZQ, Atkinson B, Wood C: 1991, Comparative evaluation of bovine immunodeficiency-like virus infection by reverse transcriptase and polymerase chain reaction. J Virol Methods 31:197-210.

15. Kertayadnya G, Wilcox GE, Soeharsino S, et al.: 1993, Characteristics of a retrovirus associated with Jembrana disease in Bali cattle. J Gen Virol 74:1769-1773.

16. McNab WB, Jacobs RM, Smith HE: 1994, A serological survey for bovine immunodeficiency-like virus in Ontario dairy cattle and association between test results, production records and management practices. Can J Vet Res 58:36-41.

17. Nadin-Davis SA, Chang SC, Smith H, Jacobs RM: 1993, Detection of bovine immunodeficiency-like virus by polymerase chain reaction. J Virol Methods 42:323-336.

18. Nash JW, Hanson LA and St. Cry Coats K: 1995, Bovine immunodeficiency virus in stud bull semen. Am J Vet Res 56: 760-763. 
19. Nash JW, Hanson LA, St. Cyr Coats K: 1995, Detection of bovine immunodeficiency virus in blood and milk-derived leukocytes by use of polymerase chain reaction. Am J Vet Res 56: 445-449.

20. Pifat DY, Ennis WH, Ward JM, et al.: 1992, Persistent infection of rabbit with bovine immunodeficiency-like virus. J Virol 66: $4518-4524$.

21. Rasmussen L, Battles JK, Ennis WH, et al.: 1990, Characterization of virus-like particles produced by a recombinant Baculovirus containing the gag gene of the bovine immunodeficiency-like virus. Virology 173:435-451.

22. Sambrook J, Fritsch EF, Maniatis T: 1989, Analysis and cloning of eukaryotic genomic DNA, In: Molecular cloning, ed. Sambrook J, Fritsch EF, Maniatis T, 2nd ed., pp 16-58. Cold Spring Harbor Laboratory Press, New York, NY.

23. St. Cyr Coats K, Pruett SF, Nash JW, Cooper CR: 1994, Bovine immunodeficiency virus: incidence of infection in Mississippi dairy cattle. Vet Microbiol 42:181-189.

24. Suarez DL, VanDerMaaten MJ, Wood C, Whetstone CA: 1993 , Isolation and characterization of new wild-type isolates of bovine lentivirus. J Virol 67:5051-5055.

25. VanDerMaaten MJ, Boothe AD, and Seger CL: 1972, Isolation of virus from cattle with persistent lymphocytosis. J Natl Cancer Inst 49:1649-1657.

26. Whetstone CA, VanDerMaaten MJ, Black JM: 1990, Humoral immune response to the bovine immunodeficiency-like virus in experimentally and naturally infected cattle. J Virol 64:35573561.

27. Whetstone CA, VanDerMaaten MJ, Miller JM: 1991, A western blot assay for the detection of antibodies to bovine immunodeficiency-like virus in experimentally inoculated cattle, sheep, and goats. Arch Virol 116:119-131. 